\title{
PENGARUH PEMAHAMAN RASIONAL PEMBIAYAAN SYARIAH DAN RELIGIUSITAS PETANI TERHADAP SIKAP PETANI DALAM MEMILIH BANK SYARIAH
}

\author{
Broto Judono ${ }^{1 *}$ \\ ${ }^{1}$ Mahasiswa Pascasarjana Fakultas Ekonomi Universitas Jember \\ *yudhono.broto@yahoo.com
}

\begin{abstract}
:
The aim of this study is to analysis the influence of the rational understanding of Islamic financing and the religiosity of farmers on the attitude of farmers in choosing Islamic Banks (Bank Syariah). This data sources are muslim farmers in Rogojampi Banyuwangi. The number of samples are 36 farmers. The result of this research shows that the attitudes of farmers in choosing Islamic Banks directly affected by the rational understanding of Islamic financing. Motive of business profit underlies the farmers to understand financing in Islamic Banks. Religiosity factors don't directly affect the attitude of farmers in choosing Islamic Banks.
\end{abstract}

Keywords: The Rational Understanding Of Islamic Financing, Religiosity, Farmer Attitude, Bank Syariah.

\section{PENDAHULUAN}

Sektor ekonomi syariah khususnya bank syariah menunjukkan peran penting dalam menopang pertumbuhan ekonomi nasional. Bank syariah merupakan salah satu pilar ekonomi syariah yang diharapkan mampu mendorong pertumbuhan ekonomi melalui penguatan permodalan. Petani merupakan salah satu individu yang memiliki frekwensi tinggi dalam berhubungan dengan jasa perbankan. Penting bagi petani yang merupakan salah satu mitra bank untuk memahami produk dan mekanisme pembiayaan syariah. Sebagai alternatif dari jasa perbankan yang sudah ada maka bank syariah diharapkan mampu menjalin mitra u saha bersama pengusaha secara produktif.

Petani merupakan individu yang memiliki frekuensi tinggi dalam berhubungan dengan jasa perbankan. Sebagai sarana pertimbangan dalam pengambilan keputusan bisnis usaha maka penting bagi petani untuk memahami bagaimana produk dan mekanisme pembiayaan di bank syariah beroperasi. Bagi petani muslim yang terikat pada ketentuan ajaran agama Islam, maka keputusan dalam memilih pembiayaan dibank syariah tidak hanya didasarkan pada motif rasional dengan mempertimbangkan faktor ekonomi semata, tetapi secara normatif juga berdasarkan atas pertimbangan-pertimbangan emosional ajaran agama. Namun demikian pada kenyataannya agama bukan merupakan faktor utama yang mendorong petani bermitra dengan bank syariah.

Sementara itu petani yang memiliki kepahaman terhadap produk dan sistim pembiayaan syariah yang sama pada kenyataanya belum tentu menghasilkan sikap yang sama dalam memilih produk pembiayaan di bank syariah. Petani yang memiliki relegiusitas tinggi tentu akan cenderung berpaling kepada ajaran-ajaran agama dalam mengambil keputusan pembiayaan bisnis pertanian. Namun di sisi lain petani harus bersifat rasional dalam mengambil keputusan bisnisnya berdasarkan motif ekonomi. Hal ini mengindikasikan bahwa perilaku rasional petani tetap menjadi landasan utama dalam pengambilan keputusan pembiayaan di bank syari'ah. Hal ini sejalan dengan teori 
agency yang menyatakan bahwa manusia diasumsikan bertindak rasional sesuai dengan motif ekonomi (Jensen $\mathrm{M}$ dan W. Meckling, 1976). Teori neoklasik menyatakan bahwa tindakan rasional mengarah pada keuntungan material atau utility (Etzioni, 1986 \& 1988).Sehingga secara umum dalam penelitian ini dihipotesiskan ada dua faktor yang mempengaruhi sikap petani muslim dalam memilih keputusan pembiayaan di bank syariah yaitu faktor pemahaman rasional tentang pembiayaan bank syariah, faktor emosional keagamaan atau relegiusitas, yang diproksikan dengan ikatan kelompok keagamaan yang sama dalam sebuah organisasi. Pemahaman rasional dalam penelitian ini diproksikan dengan pemahaman petani atas produk pembiayaan bank syariah. Pemahaman rasional petani tentang produk pembiayaan bank syariah menyatakan bahwa pembiayaan di bank syariah menguntungkan secara bisnis. Alasan utama seorang petani memilih pembiayaan di bank syariah karena secara ekonomi sistim mudharobah sejalan dan menguntungkan secara bisnis. Sistim bagi hasil yang sesuai dengan proposi modal dipahami petani sebagai sistim yang sejalan dan menguntungkan.

Petani yang memiliki pemahaman terhadap produk dan sistim pembiayaan syariah yang sama pada kenyataanya belum tentu menghasilkan sikap yang sama dalam memilih produk pembiayaan dibank syariah. Petani yang memiliki relegiusitas tinggi tentu akan cenderung berpaling kepada ajaran-ajaran agama dalam memilih produk pembiayaan syariah di bank syariah. Namun disisi lain petani harus bersifat rasional dalam mengambil keputusan bisnisnya berdasarkan motif ekonomi. Berdasarkan hal tersebut maka permasalahan dapat dirumuskan dalam pertanyaan penelitian sebagai berikut : Apakah pemahaman rasional pembiayaan bank syariah, relegiusitas petani mempengaruhi sikap petani dalam memilih pembiayaan syariah di bank syariah?
Tujuan penelitian ini untuk menguji pengaruh pemahaman rasional pembiayaan bank syariah, relegiusitas petani terhadap sikap petani dalam memilih pembiayaan syariah di bank syariah.

\section{KAJIAN PUSTAKA}

Di beberapa negara penelitian tentang motif bermitra dengan bank syariah pernah dilakukan meskipun tidak secara khusus meneliti tentang prilaku petani dalam kaitannya dengan pembiayaan di bank syariah. Penelitian di Qatar menemukan bukti bahwa faktor relegiusitas menjadi alasan utama pelanggan bergabung dengan bank Islam. Dalam kondisi pelayanan yang kurang memuaskan pelanggan bank Islam di Qatar cenderung tidak memiliki keinginan berpindah ke bank konvensional. Hal ini karena di Qatar faktor relegiusitas sangat dominan. Namun belum ditemukan bukti empiris petani berpindah bank karena alasan relegiusitas. Sementara itu hasil penelitian di Singapura ditemukan bukti bahwa ketika faktor relegiusitas dikombinasikan dengan alasan-alasan ekonomis maka jawaban responden cenderung memilih bank syariah (Woldie dan Al Hajri, 2004).

Sedangkan penelitian tentang preferensi nasabah bank di Jordania menemukan bukti bahwa relegiusitas menempati urutan kedua dalam motivasi nasabah bermitra dengan bank syariah. Sedangkan penelitian terhadap respon petani dengan beroperasinya bank syariah di Indonesia yaitu di Kecamatan Rogojampi Kabupaten Banyuwangi, menyatakan bahwa preferensi petani bermitra dengan bank syari'ah 59,3\% karena dimotivasi oleh pemahaman produk syariah, $25,90 \%$ karena pemahaman sistim mekanisme keuangan bank syari'ah, dan $14,8 \%$ karena faktor relegiusitas (BNI Syari'ah, 2007).

Penelitian yang dilakukan Hardiwinoto (2012) menemukan bukti bahwa motif rasional merupakan pendorong utama manager merespon bank syariah. Hal tersebut berbeda dengan penelitian yang dilakukan oleh Haron, Sudin Norafifah, Ahcmad, dan Sandra L. Plenisek,1994 
menemukan bukti bahwa dorongan bermitra dengan bank syariah adalah karena faktor emosional yaitu solidaritas keagamaan. Karena beragamnya hasil - hasil penelitian tersebut maka penelitian ini mencoba mencari bukti baru yang diharapkan akan dapat menjelaskan beragamnya hasil penelitian.

\section{Pemahaman Rasional Petani}

Menurut teori agency bahwa manusia diasumsikan bertindak rasional sesuai dengan motif ekonomi (Jensen $\mathrm{M}$ dan W. Meckling, 1976). Teori neo klasik menyatakan bahwa tindakan rasional mengarah pada keuntungan material atau utility (Kahneman, D., 1991; Etzioni, 1986 \& 1988; Tversky,A \& Kahmen, 1986). Tindakan rasional dipengaruhi oleh alokasi sumber daya (Moon, et al, 2003); penghitungan cost of benefit (Bouffard et al, 2010); serta kumpulan dan pemahaman informasi (Scholten, 2007; March, 1978). Sikap petani dihipotesiskan dipengaruhi oleh motif-motif rasional dibanding dengan motif emosional. Dihadapkan pada pilihan-pilihan bisnis maka petani memiliki kecenderungan untuk kembali pada sifat dasarnya sebagai manusia rasional yang lebih mementingkan keuntungan materiil atau utility.

Bank syariah adalah bank yang mekanisme pembiayaannya mengacu pada prinsip-prinsip ajaran agama Islam tentang muammalah atau pedagangan. Meskipun dilandasi oleh semangat keagamaan namun bank syariah tetap mengedepankan prinsip utama bisnis yaitu mengambil keuntungan. Petani memilih pembiayaan di bank syariah karena dilandasi oleh keinginan mendapatkan keuntungan atau profit. Keinginan tersebut merupakan motif yang rasional. Sehingga dapat dijabarkan bahwa sikap petani dalam memilih produk pembiayaan di bank syariah karena secara rasional petani memiliki pemahamanbahwa produk pembiayaan bank syariah menguntungkan secara bisnis, adil dan bermanfaat. Indikator pemahaman rasional petani diukur dengan sejauh mana petani ingin mengejar atau meraih laba ekonomi dalam bermitra dengan bank syariah.

\section{Pemahaman Religiusitas}

Selain sikap rasional yang ditunjukkan oleh petani yang ingin mencari untung akan tetapi disisi lain petani juga memiliki latar belakang relegiusitas dan ikatan priomordialisme yang bisa mempengaruhi sikap emosional petani. Relegiusitas berasal dari bahasa latin relegio yang berarti mengikat. Ini mengandung makna bahwa dalam religi atau agama memiliki aturanaturan atau kewajiban - kewajiban yang harus dipatuhi oleh para pengikutnya. Semua itu berfungsi untuk mengikat seseorang atau sekelompok orang dalam hubungannya dengan Tuhan,sesama manusia, dan alam sekitarnya. Sehingga dapat disimpulkan bahwa relegiusitas menunjuk pada tingkat keterikatan individu pada agamanya,( Stark dalam Wahyuni 2010).

Religiusitas berasal dari bahasa latin relegio yang berarti mengikat. Ini mengandung makna bahwa dalam religi atau agama memiliki aturan-aturan atau kewajiban - kewajiban yang harus dipatuhi oleh para pengikutnya. Semua itu berfungsi untuk mengikat seseorang atau sekelompok orang dalam hubungannya dengan Tuhan,sesama manusia, dan alam sekitarnya. Sehi ngga dapat disimpulkan bahwa relegiusitas menunjuk pada tingkat keterikatan individu pada agamanya. Indikator dalam relegiusitas menurut Glock dan Stark dalam Wahyuni (2004) adalah sebagai berikut :

a. Keyakinan yaitu sejauh mana individu mengakui hal-hal yang bersifat dogmatik dalam agamanya, misalnya tentang kekuasaan Tuhan, malaikat, surga dan neraka.

b. Peribadatan yaitu sejauh mana individu melaksanakan ritual dalam agamanya, misalnya : zakat, puasa, haji, dan sebagainya.

c. Penghayatan yaitu perasaan keagamaan yang dialami dan dirasakan misalnya perasaan bersalah takut berbuat dosa. 
d. Pengetahuan agama yaitu sejauh mana individu memahami agamanya misalnya pengetahuan tentang fiqh muamalah atau jual beli.

e. Pengamalan yaitu sejauh mana implikasi agama mempengaruhi prilaku individu dalam kehidupan social, misalnya mendermakan harta,memilih produk yang halal dan sebainya.

\section{Sikap Petani}

Menurut teori tentang sikap, Robin (2004) mendefinisikan sikap sebagai pernyataan-pernyataan evaluatif-baik yang diinginkan atau yang tidak diinginkan mengenai objek, orang, atau peristiwa. Sikap mencerminkan bagaimana seseorang merasakan sesuatuse hari - hari. Sikap pada hakikatnya adalah kecenderungan berperilaku pada seseorang.Ajzen (2006) memberikan formula norma subyektif dalam persamaan berikut: $\mathrm{SN} \alpha \Sigma$ nimi; $\mathrm{SN}=$ subjective norm, $\mathrm{n}=$ norma-tive beliefs, dan $\mathrm{m}=$ motivation to comply. Sedangkan Hardiwinoto (2012) menjabarkan sikap yang tercermin dalam tiga indikator yang membentuk sikap yaitu kognitif, afektif, dan perilaku. Pemahaman rasional tentang pembiayaan bagi hasil (profit and loss sharing) dalam bank adalah menguntungkan secara bisnis. Hal semacam ini merupakan komponen kognitif dari sikap.Sedangkan komponen afektif adalah segmen emosional atau perasaan dari sikap yang dicerminkan dalam pernyataan keinginan untuk mencari informasi lebih dalam lagi tentang pembiayaan syariah. Komponen prilaku ditunjukkan dengan pernyataan kongkret yaitu saya akan bermitra dengan bank syariah karena bank syariah yang menggunakan sistim keuangan bagi hasil adalah menguntungkan secara bisnis.

\section{METODE}

Hipotesis yang akan diajukan dalam penelitian ini berdasarkan telaah pustaka dan landasan teori seperti yang telah dipaparkan pada sub bab sebelumnya. Berdasarkan hal itu, maka hipotesis yang diajukan adalah sebagai berikut :

$\mathrm{H}_{1}=$ Ada hubungan positiF antara relegiusitas dengan sikap petani dalam memilih produk pembiayaan di bank syariah.

$\mathrm{H} 2=$ Ada hubungan positif antara pemahaman rasional pembiayaan syariah dengan sikap petani dalam memilih produk pembiayaan di bank syari'ah.

Jenis data yang digunakan dalam penelitian ini adalah data primer. Data primer yang diperlukan dalam penelitian ini adalah data yang didapatkan dari jawaban para responden terhadap pertanyaan yang diajukan oleh peneliti. Data yang diperlukan adalah jawaban responden mengenai relegiusitas, kepahaman produk dan mekanisme pembiayaan syariah, dan sikap petani dalam memilih pembiayaan di bank syariah. Jenis data yang dipakai dalam penelitian ini adalah data primer (primary data). Sumber data diambil dari populasi petani muslim di Kecamatan Rogojampi Kabupaten Banyuwangi, dengan jumlah sampel yang diambil sebanyak 36 petani.

Metode pengumpulan data dilakukan dengan menggunakan metode survei dengan kuesioner (self report). Kuesioner digunakan untuk mendapatkan data tanggapan responden mengenai dimensi dari konstrukkonstruk yang dikembangkan dalam penelitian. Pernyataan - pernyataan dalam angket tertutup dibuat dengan menggunakan skala likert 1 - 5 untuk mendapatkan data yang bersifat interval dan diberi skor. Jawaban kuesioner yang diharapkan adalah dengan memberikan tanda $(\mathbf{X})$ pada 5 skala sikap (Semantic Differentiation Scale) yang dirasakan paling benar oleh responden atas pertanyaan - pertanyaan dalam kuesioner. Adapun perhitungan skala likert 1 sampai dengan 5 adalah sebagai berikut :

Jawaban 1 berarti tidak setuju dan akan mendapat skor 1

Jawaban 2 berarti agak setuju dan akan mendapat skor 2 
Jawaban 3 berarti ragu-ragu dan akan mendapat skor 3

Jawaban 4 berarti setuju dan akan mendapat skor 4

Jawaban 5 berarti sangat setuju dan akan mendapat skor 5

Pengujian dalam penelitian ini menggunakan model persamaan regresi berganda yang mewakili analisa tersebut adalah sebagai berikut:

$\mathrm{Y}=\mathrm{b} 0+\mathrm{b} 1 \mathrm{X}_{1}+\mathrm{b} 2 \mathrm{X}_{2}+\mathrm{b} 3 \mathrm{X}_{3}+\mathrm{e}$

Dimana :

$\mathrm{Y}=$ Sikap petani dalam memilih pembiayaan di bank syari'ah

$\mathrm{X}_{1}=$ Relegiusitas

$\mathrm{X}_{2}=$ Primordialisme

$\mathrm{X}_{3}=$ Pemahaman rasional pembiayaan perbankan syari'ah

$\mathrm{e}=$ Error

\section{HASIL DAN PEMBAHASAN}

Tabel 1. Analisa Statistik

\begin{tabular}{|c|c|c|c|c|c|}
\hline \multirow[t]{2}{*}{ Model } & \multicolumn{2}{|c|}{$\begin{array}{l}\text { Unstandarizzed } \\
\text { Coefficients }\end{array}$} & $\begin{array}{c}\text { Standardize } \\
d\end{array}$ & \multirow[t]{2}{*}{$t$} & \multirow[t]{2}{*}{ Sige } \\
\hline & \begin{tabular}{|l|} 
B \\
\end{tabular} & Std. Enror & Bet & & \\
\hline (Constant) & 6886 & 287 & & 238 & .02 \\
\hline Religi & .022 & .025 & .118 & 87 & 39 \\
\hline I_PP & 723 & $\mid$ &. & 7.00 & .00 \\
\hline
\end{tabular}

Sumber : data diolah

Hasil penelitian menunjukkan bahwa hipotesis 1 ditolak. Tidak terbukti ada pengaruh langsung antara relegiusitas dengan sikap petani dalam memilih pembiayaan di bank syariah dengan tingkat sig. 0,390. Hanya dalam hipotesis 2 dapat dibuktikan ada hubungan secara langsung antara pemahaman rasional petani tentang pembiayaan bank syariah dengan sikap petani dalam memilih pembiayaan di bank syariah. Hasil penelitian juga menunjukkan $\mathrm{R}$ square 0,643 . Artinya bahwa variabelvariabel dalam penelitian dapat menjelaskan model penelitian sebesar $64,3 \%$ Beta positif menandakan arah penelitian ini sudah sesuai dengan landasan teori yang dibangun. Dalam kaitannya dengan hipotesis 3 rata-rata responden sependapat bahwa pembiayaan syariah menguntungkan dari sisi bisnis. Jawaban responden juga menunjukkan bahwa unsur spekulasi sangat dihindari. Petani memilih pembiayaan bank syariah karena adanya kepastian dalam pembagian keuntungan. Petani memandang bahwa sistim bagi hasil (loss and profit sharing) sangat menguntungkan dan sejalan dengan tujuan dan kepentingan bisnis yang dijalankan

Hasil penelitian tersebut secara keseluruhan searah dengan landasan utama teori tentang tindakan rasional bahwa pada hakekatnya manusia memiliki kecenderungan untuk berlaku rasional dalam mengambil keputusan .Arah beta positip menunjukkan hasil penelitian arahnya sudah sesuai dengan teori yang dibangun. Ditolaknya hipotesis 1 bisa dijelaskan bahwa bisa jadi relegiusitas bukan merupakan variabel independent yang memepengaruhi secara langsung sikap petani.

Dalam teori neoklasik manusia cenderung untuk berlaku rasional. Petani yang memiliki relegiusitas tinggi tidak otomatis akan mempengaruhi sikap petani dalam memilih pembiayaan di bank syariah. Sikap petani lebih dipengaruhi oleh pemahaman rasional petani terhadap produk dan pebiayaan di bank syariah. Pemahaman rasional petani secara langsung mempengaruhi sikap petani karena secara rasional pada hakekatnya melakukan pembiayaan di bank syariah menguntungkan dari sisi bisnis bisa diterjemahkan sebagai sikap yang rasional. Dihadapkan pada pilihan pembiayaan di bank syariah ternyata petani lebih mengutamakan keputusan yang bersifat rasionalitas dan cenderung mengesampingkan sikap emosional. Sehingga dapat dipahami jika hipotesis 2 tersebut diterima bisa dipahami.

Dalam jawaban kuesioner rata-rata petani menjawab sangat setuju jika sistim bagi hasil yang ditawarkan oleh bank syariah sangat menguntungkan bagi praktek bisnis mereka. Dengan demikian motif mengejar keuntungan bisnis melandasi 
pemahaman petani tentang produk pembiayaan bank syariah. Namun disisi tingginya relegiusitas yang ditunjukkan dalam jawaban kuesioner petani ternyata tidak berpengaruh secara siqnifikan terhadap sikap petani dalam memutuskan pembiayaan di bank syariah. Hal ini mengindikasikan bahwa petani lebih bersikap rasional daripada bersikap emosional ketika dihadapkan pada pilihan dalam pembiayaan di bank syariah. Namun sayangnya dalam penelitian ini tidak didisain untuk mencari pola atau model hubungan antara sikap emosional petani dan sikap rasional dengan sikap petani dalam memilih pembiayaan di bank syariah.

\section{KESIMPULAN DAN SARAN}

Kesimpulan dalam penelitian ini adalah bahwa sikap petani dalam memilih pembiayaan di bank syariah lebih dipengaruhi secara langsung oleh faktor pemahaman rasional pembiayaan syariah. Faktor mengejar keuntungan maksimal atau laba usaha mendasari pemahaman petani tentang pembiayaan bank syariah. Sedangkan relegiusitas dan priomordialisme tidak terbukti secara langsung mempengaruhi sikap petani dalam memilih pembiayaan di bank syariah.

\section{DAFTAR PUSTAKA}

Ajzen, I.2005. Attitude, Personality, and Behavior.2nd Edition. Berkshire, UK Open University Press-McGraw Hill Education.

Ascarya, Diana Yumanita, dan Noer Azam Achsani, Gruh S, 2008, Comparing the Efficiency of Conventional and Islamic Banks in Indonesia using Parametric and Nonarametric Approaches, Bank Indonesia, Jakarta Bank Indonesia, 2006, Booklet Perbankan Indonesia, Direktorat Perijinan dan Informasi Perbankan.

Bouffard,J.A, et al, 2010, Methodological Artifacts in Test of Rational Choice Theory, Journal of Criminal Justice, Vol.38, pp. 400-409
Craven, DW.1995, Pemasaran Strategis Jilid II (Indonesia edition), Erlangga Publiser. Etzioni A.,1986, Rationality Is Anti-Entropic, Journal of Economic Psycology, Vol. 7, pp.1736 Noth-Holland

Etzioni A.,1988, Normative-Affective factors : Toward A New Decision Making Model,,Journal of Economic Psycology, Vol. 9, pp.125-150 NothHolland

Etzioni A.,2010, Behavioral economic: A Methodological Note, Journal of Economic Psycology, Vol. 31, NothHolland

BNI Syari'ah, 2007, Peluang dan Tantangan Bank Syari'ah di Indonesia, AlKautsar Prima, Jakarta.

Geertz,Clifford, 1973, The Interpretation of Cultures, Basic Book, Inc, New York, hal 259

Hardiwinoto, 2012, Analallisis Faktor Emosional dan Rasional dalam Keputusan Pembiayaan Perusahaan Melalui Bank

Haron, et al, 1994, Bank Patronase Factors of Muslim and Non Muslim Customer, International Journal of Bank Mareketing, Vol. 12 No. 1, pp. $32-40$

Isgiarta, Jaka, 2008, Tujuan Laporan Keuangan Islami, paper disajikan pada International Seminar and Symposium IAIE, Surabaya. 